\title{
Sucrose concentration and volume of liquid medium on the in vitro growth and development of blackberry cv. Tupy in temporary immersion systems
}

\author{
Concentração de sacarose e do volume de meio líquido no crescimento e \\ desenvolvimento in vitro da amoreira cv. Tupy em um sistema de imersão temporária
}

\author{
Ricardo Antônio Ayub ${ }^{1 *}$ (D) Jessé Neves dos Santos ${ }^{1}$ (D) , Luiz Antônio Zanlorensi Junior ${ }^{2}$ (D), \\ Daurimar Mendes da Silva' ${ }^{1}$, Tereza Cristina de Carvalho ${ }^{3}$ (D) Fernanda Grimaldi ${ }^{1}$ (D)
}

\author{
${ }^{1}$ Universidade Estadual de Ponta Grossa/UEPG, Departamento de Fitotecnia e Fitossanidade, Ponta Grossa, PR, Brasil \\ Universidade Federal do Paraná/UFPR, Departamento de Informática, PR, Brasil \\ ${ }^{3}$ Centro de Ensino Superior dos Campos Gerais/CESCAGE, Ponta Grossa, PR, Brasil \\ *Corresponding author: rayub@uepg.br \\ Received in April 1, 2019 and approved in September 10, 2019
}

\begin{abstract}
Micropropagation of small fruits such as blackberry has been employed due to the need to obtain plants with high phytosanitary quality. Bioreactor technology has been used to improve efficiency in seedling production. Thus, the objective of this work was to evaluate the best culture medium volume and sucrose concentration for blackberry micropropagation in a temporary immersion bioreactor. In vitro blackberry shoots were segmented containing two buds and an internode $(1.0 \mathrm{~cm})$ and placed into MS medium supplemented with inositol $\left(0.1 \mathrm{~g} \mathrm{~L}^{-1}\right)$, BAP (1 $\left.\mathrm{mg} \mathrm{L}^{-1}\right)$ and sucrose $\left(10,20,30\right.$ or $\left.40 \mathrm{~g} \mathrm{~L}^{-1}\right)$ at different medium volumes (150, 175 and $\left.200 \mathrm{~mL}\right)$. The total length, number of leaves, number of shoots, and number of hyperhydric shoots were evaluated 56 days after start of the project. For blackberry development and propagation in a bioreactor system, the best results were shown at a medium volume of $175 \mathrm{ml}$ and a sucrose concentration of $20 \mathrm{~g} \mathrm{~L}^{-1}$.
\end{abstract}

Index terms: Rubus spp.; clonal propagation; hyperhydricity.

\begin{abstract}
RESUMO
O uso de micropropagação de pequenos frutos como a amoreira-preta tem sido empregado devido à necessidade de obtenção de plantas com alta qualidade fitossanitária. A tecnologia de biorreatores tem sido usada para melhorar a eficiência na produção de mudas. Assim, o objetivo deste trabalho foi avaliar a melhor quantidade de meio de cultura e a concentração ideal de sacarose para micropropagação de amoreira-preta em um biorreator de imersão temporária. Brotações in vitro de amoreira-preta foram segmentadas contendo duas gemas com internódio $(1.0 \mathrm{~cm})$ e colocadas em meio MS suplementado com inositol $\left(0.1 \mathrm{~g} \mathrm{~L}^{-1}\right)$, BAP (1 mg L-1), sacarose $(10,20,30$ ou 40 $\mathrm{g} \mathrm{L}^{-1}$ ) e volume de meio (150, 175 e $200 \mathrm{~mL}$ ). Foram avaliados aos 56 dias, o comprimento total, número de folhas, número de brotações e brotações hiper-hídricas. O volume de $175 \mathrm{~mL}$ e a concentração de $20 \mathrm{~g} \mathrm{~L}^{-1}$ apresentaram os melhores resultados e são os mais recomendados para o desenvolvimento e propagação de amora-preta em um sistema de biorreatores.
\end{abstract}

Termos de indexação: Rubus spp.; propagação clonal; hiperidricidade.

\section{INTRODUCTION}

The blackberry (Rubus spp.) belongs to the small fruit group, and its production in Brazil is concentrated in the South and Southeast regions. Its nutraceutical properties, low production cost and low supply in the market result in an increase in fruit demand and good sale value. (Augusto; Biasi; Telles, 2006; Silva et al., 2016; Tullio; Ayub, 2013). However, as with most fruits, the purchase of plants represents the highest cost for orchards, and it is necessary to use techniques to reduce expenses in the production process (Attilio; Boliani; Tarsitano, 2009).

Among the techniques used for plant production, micropropagation is a very important contributor to the development of healthy plants, as this technique maintains genetic and phytosanitary quality. The conventional technique of micropropagation requires high labour, the 
use of a large quantity of containers (Teixeira, 2011) and semi-solid culture medium, which, in addition to sucrose, low light intensity and high relative humidity in the containers, can reduce the photosynthetic potential and stomatal functionality, generating a lower rate of multiplication and biomass, thus making the technique more expensive (Hazarika, 2006; Lemos, 2013).

With this perspective, another option for in vitro plant development is the use of liquid medium, allowing greater contact of the medium with the explant and providing greater nutrient absorption (Rodrigues et al., 2006). Moreover, using liquid medium enables the automation of the process, presenting advantages for reducing labour and production costs (Silva et al., 2007; Teixeira, 2011; Georgiev et al., 2014). However, the use of liquid medium should be optimized for each species and condition, since it is more propitious to water accumulation in the plant's apoplast, which decreases gas exchange with the external environment and causes oxidative stress and, as a consequence of the plant morphology, generates a vitreous state (Rojas-Martínez; Visser; Klerk, 2010; Dries et al., 2013).

Cloudberry (Rubus chamaemorus) was the first species of the genus Rubus studied in a bioreactor using a permanent immersion system (Debnath, 2007; Debnath, 2011), and raspberry (Rubus idaeus) was studied using a temporary immersion system (Debnath, 2014). For blackberry, at present, there are no reports using a bioreactor system for seedling production. Therefore, this study aims to evaluate blackberry micropropagation in a temporary immersion bioreactor by adjusting the culture medium volume and sucrose concentration.

\section{MATERIAL AND METHODS}

\section{Plant material}

Blackberry (Rubus spp.) cultivar Tupy was previously cultivated in vitro in semi-solid Murashige and Skoog (1962) medium (MS) supplemented with $0.1 \mathrm{~g} \mathrm{~L}^{-1}$ inositol, $1 \mathrm{mg} \mathrm{L}^{-1}$ 6-benzylaminopurine (BAP), $30 \mathrm{~g} \mathrm{~L}^{-1}$ sucrose and $6 \mathrm{~g} \mathrm{~L}^{-1}$ agar. The $\mathrm{pH}$ was adjusted to 5.8. After 60 days, the shoots were used for the experiments. Shoot segments $1 \mathrm{~cm}$ long with 2 buds were used as explants from the entire plant.

\section{Bioreactor system}

The bioreactor used was based on a line system and is divided into two modules (logical and physical). The logic module is responsible for configurating, managing and monitoring the bioreactor and consists of two levels. The first level is executed by software, which communicates with the second level, consisting of a microcontroller. The second level interacts directly with the physical module, sending instructions that are performed by the bioreactor pneumatically. These instructions consist of opening and closing solenoids, and through these actions, the culture medium is transferred between the containers (Zanlorenzi Junior et al., 2017) (patent deposit BR202017008054 - 0, 19 Apr. 2017).

A double container system (Figure 1), one for the explants and the other for the culture medium liquid, was also used. The medium was transferred every 4 hours between the containers and remained in the explant container for 20 seconds. After the culture medium was added to the containers, they were autoclaved at $120^{\circ} \mathrm{C}$ for 20 minutes before experimental installation under laminar flow.

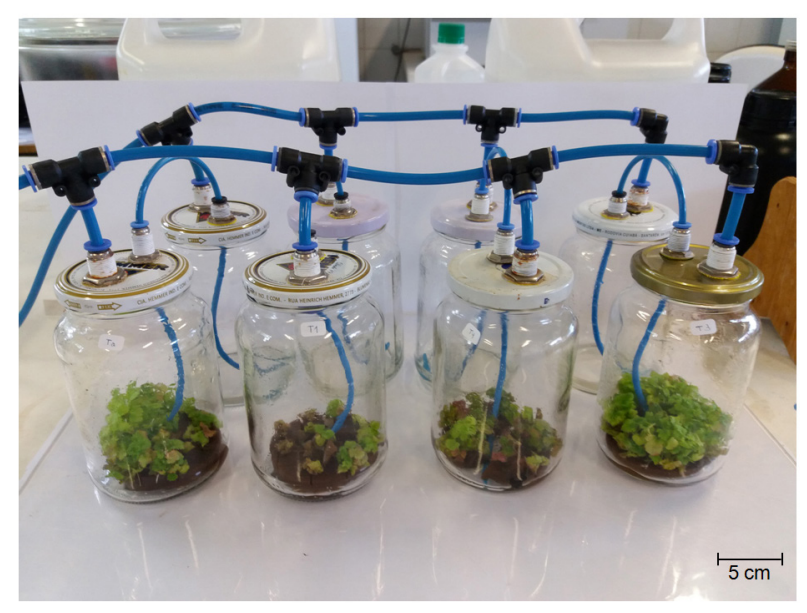

Figure 1: Bioreactor with dual container system (500 $\mathrm{mL}$ capacity).

\section{Experiment 1: Volume of liquid medium}

In the bioreactor system, 3 pairs of containers (1 L total capacity) were used to test three volumes of liquid medium: 150, 175 and $200 \mathrm{~mL}$. The liquid medium was MS supplemented with $0.1 \mathrm{~g} \mathrm{~L}^{-1}$ inositol, $30 \mathrm{~g} \mathrm{~L}^{-1}$ sucrose and $1 \mathrm{mg} \mathrm{L}^{-1} \mathrm{BAP}$, with the $\mathrm{pH}$ adjusted to 5.8. All chemicals were obtained from Sigma ${ }^{\circledR}$. In each container, 20 explants $(1.0 \mathrm{~cm})$ of blackberry were fixed in phenolic foam, and after 56 days, the number of leaves, number of shoots, plant total length, plant fresh weight and root length were evaluated. 


\section{Experiment 2: Sucrose concentration}

In the bioreactor system, 4 pairs of containers $(500 \mathrm{~mL}$ total capacity) were used to test four sucrose concentrations: 10, 20, 30 and $40 \mathrm{~g} \mathrm{~L}^{-1}$. The liquid medium was MS supplemented with $0.1 \mathrm{~g} \mathrm{~L}^{-1}$ inositol and $1 \mathrm{mg} \mathrm{L}^{-1}$ BAP, with the $\mathrm{pH}$ adjusted to 5.8. In each container, 10 explants of blackberry were fixed in phenolic foam and $90 \mathrm{~mL}$ of culture medium, which was proportional to the best amount of medium obtained in experiment 1 . After 56 days, the number of roots, rooting rate, length of the largest root, total length, number of shoots, length of the largest shoot, total number of leaves, number of healthy leaves, number of dead leaves, number of hyperhydric leaves, number of hyperhydric shoots and plant fresh weight were evaluated.

\section{Growth conditions}

For all experiments described below, the growth room was set to $25 \pm 2{ }^{\circ} \mathrm{C}$ with a 16-hour photoperiod and a white light photon flux density of $27 \mu \mathrm{mol} \mathrm{m}^{-2} \mathrm{~s}^{-1}$.
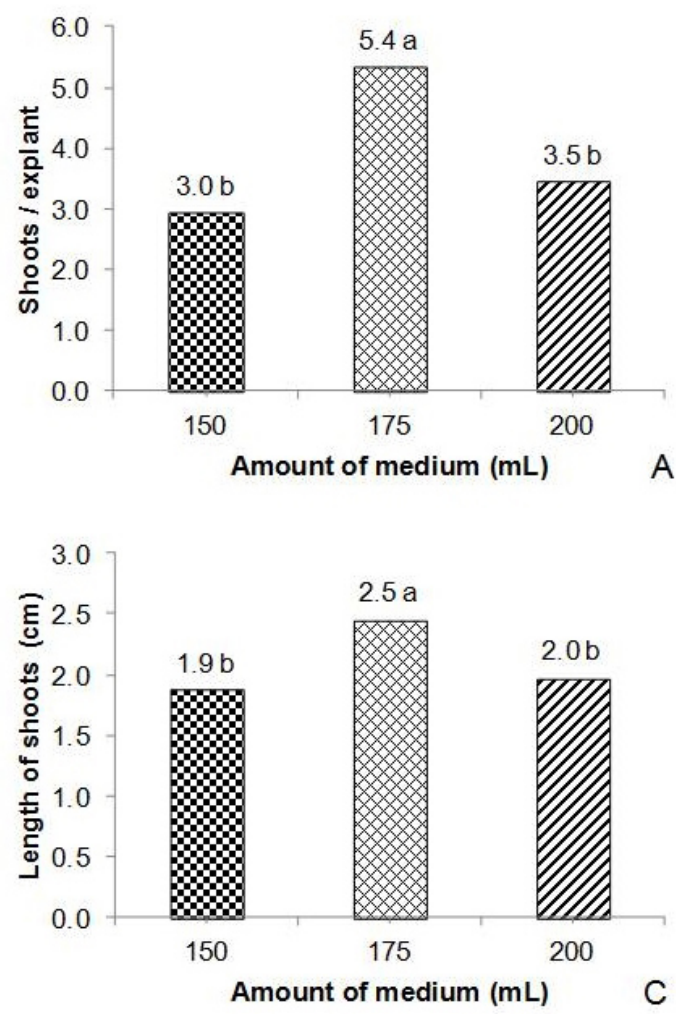

\section{Statistical design}

All experiments were performed in a completely randomized design with 4 replicates. The data were subjected to analysis of variance (ANOVA), the ScottKnott test and polynomial regression using the statistical program Sisvar (Ferreira, 2014). The maximum point was calculated through regression derivation of the obtained functions.

\section{RESULTS AND DISCUSSION}

In the experiment evaluating the amount of culture medium, the number of shoots (Figure $2 \mathrm{~A}$ ) per explant was $44 \%$ and $35 \%$ higher using $175 \mathrm{~mL}$ than using 150 and $200 \mathrm{~mL}$, respectively. The number of leaves per explant, total plant length, and plant fresh weight (Figure $2 \mathrm{~B}, \mathrm{C}$ and D) were significantly different by the Scott-Knott test as well. These results indicate greater efficiency in plant multiplication and development using $175 \mathrm{~mL}$ of culture medium.
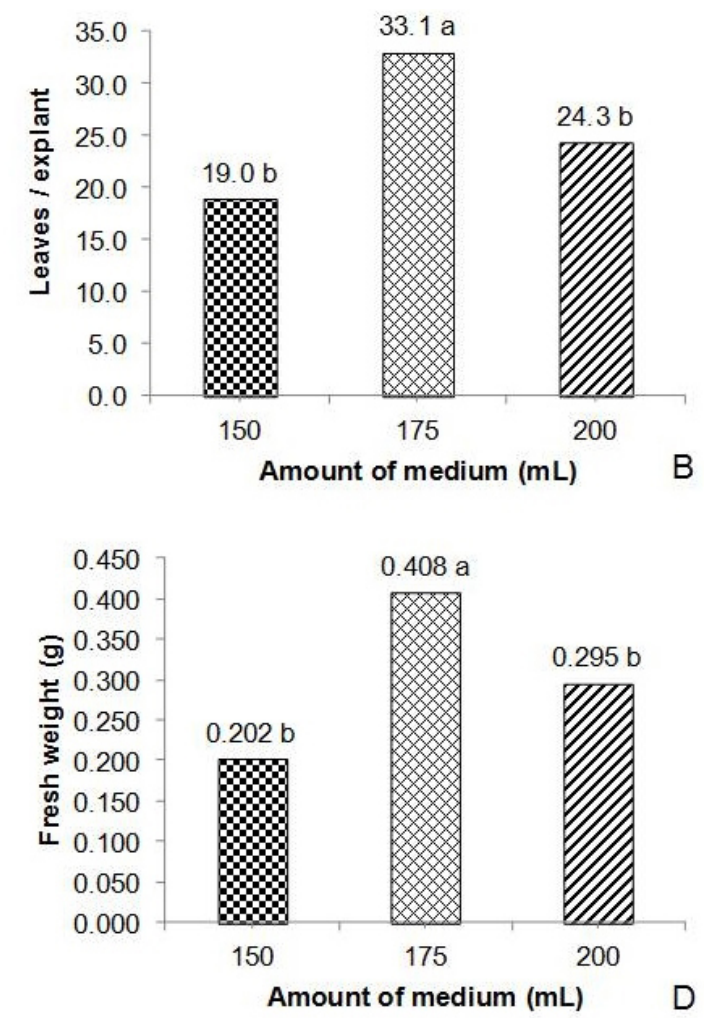

Figure 2: Number of shoots per explant (A), number of leaves per explant (B), length of shoots (C) and plant fresh weight (D) by culture medium volume for blackberry micropropagation in a temporary immersion bioreactor. Means followed by the same lowercase letters do not differ statistically between treatments by the Scott-Knott test $(p \leq 0.05)$. 
The multiplication rate in temporary immersion systems is one of the micropropagation variables that determines the success of the technique, because this technique is expected to obtain a high number of shoots per explant. Erig, Ross and Forte (2002) used $1 \mathrm{mg} \mathrm{L}^{-1}$ BAP in the Tupy cultivar and obtained 3.23 shoots per explant using MS solid medium. Hunková, Libiaková and Gajdosová (2016) obtained 2.34, 2.9, 3.6 and 4.0 shoots per explant for Rubus $s p$. cultivars Black Jewel, Tayberry, Tulameen, and Blacksatin, respectively, using MS semisolid medium with $1 \mathrm{mg}$ $\mathrm{L}^{-1} \mathrm{BAP}$ and $0.2 \mathrm{mg} \mathrm{L}^{-1}$ IBA. Welander et al. (2014) studied Rubus idaeus in a temporary immersion bioreactor and obtained 3.74 shoots per explant. In our experiment with the amount of culture medium, the 5.4 shoots / explant obtained (Figure 2A) was higher than the values reported in these studies, while in the sucrose experiment, our results were similar (3.9 shoots / explant).

Obtaining the best average number of shoots per explant with $175 \mathrm{~mL}$ medium can be explained by the equilibrium generated in the moisture of the container, without the rapid loss of water by the explants, without toxicity caused by the increase in nutrient concentration, and without water accumulation in the plant tissues, as observed in the other treatments. These factors added to the consistency of the medium, which favours greater absorption of nutrients and leads to greater plant growth (Rodrigues et al., 2006).

In the experiment evaluating the sucrose concentration, root formation in the plants was minimal because there was no addition of auxin to the culture medium. However, a sucrose concentration of $20 \mathrm{~g} \mathrm{~L}^{-1}$ had the highest rooting percentage $(23 \%)$, while $10 \mathrm{~g}$ $\mathrm{L}^{-1}$ had the highest number of roots per explant (0.6) (Figure 3) but also a higher number of hyperhydric shoots per explant (1.1).

With $10 \mathrm{~g} \mathrm{~L}^{-1}$ sucrose, there was a decrease in root development, number of shoots, shoot length, total length, total number of leaves, number of leaves and fresh weight (Figure 4). The lowest performance of these variables was observed with $40 \mathrm{~g} \mathrm{~L}^{-1}$ sucrose (Figure 4).

Culture medium sucrose availability is considered a factor that may influence explant growth (Lemes et al., 2016; Ribeiro et al., 2008). Its importance is related to the fact that the explant depends on a source of energy to enable the normal activity of the physiological functions of the cell, such as respiration. This dependence occurs because the photosynthesis process does not occur normally due to the lack of $\mathrm{CO}_{2}$.
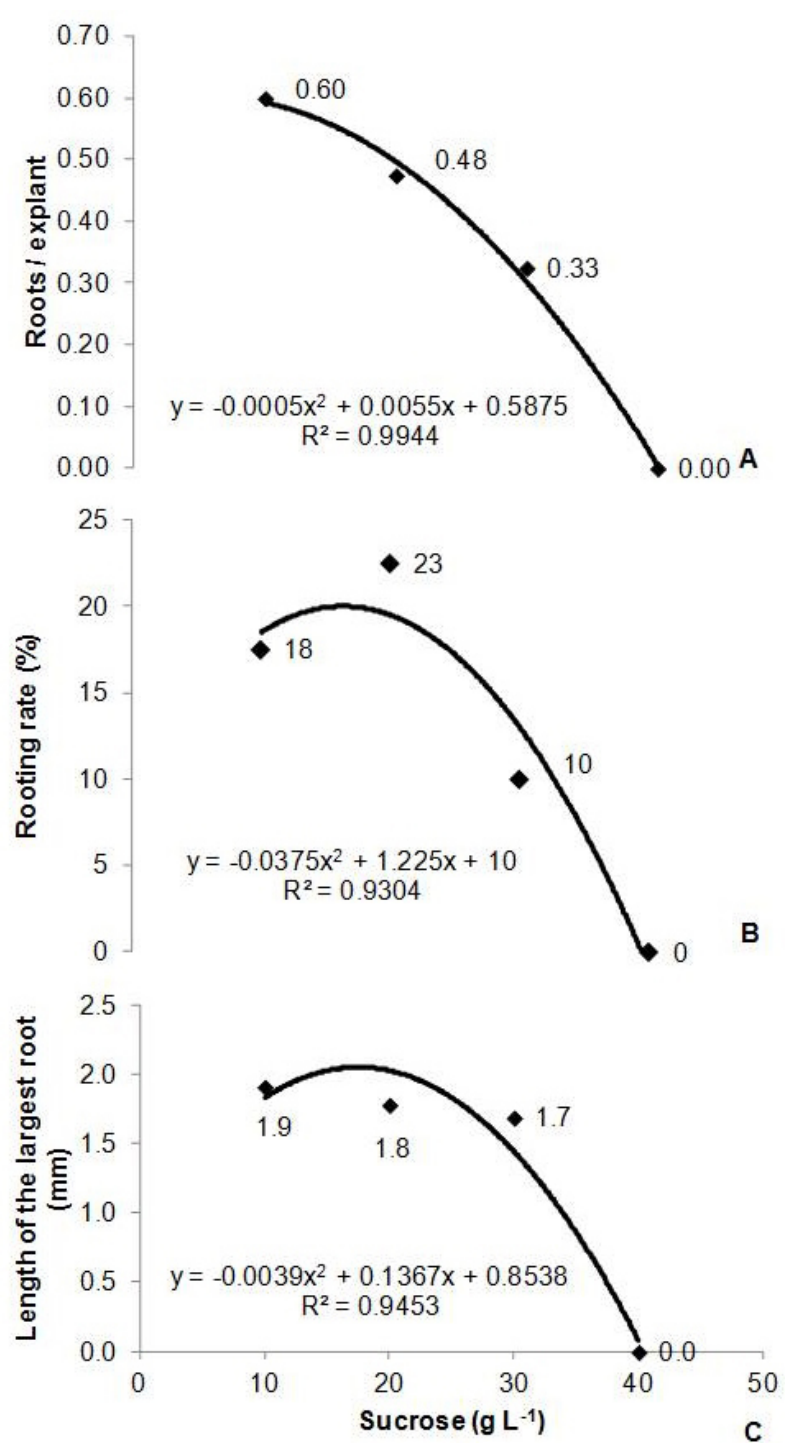

Figure 3: Sucrose influence on blackberry root development. (A) Number of roots per explant, (B) rooting rate and (C) length of the largest root during micropropagation in a temporary immersion bioreactor.

By analysing the results presented in Figure 4, it was verified that the number of shoots of blackberry plants (Figure 4A) was highest when $10 \mathrm{~g} \mathrm{~L}^{-1}$ sucrose was used. Above this concentration of sucrose, there was a decline in the number of shoots. Lemes et al. (2016) found no beneficial effects on the number of shoots when sucrose was used in Miltonia flavescens culture medium.

When analysing the length of the largest shoot (Figure 4B) and total length (Figure 4C), the best growth result for blackberry plants was obtained with $20 \mathrm{~g} \mathrm{~L}^{-1}$ 
sucrose in the culture medium. Meanwhile, the total number of leaves (Figure 4D) was highest when 20-30 g $\mathrm{L}^{-1}$ sucrose was adopted. Thus, the best response regarding the development of blackberry plants was provided with the lower concentrations of sucrose.

An increase in sucrose availability up to $40 \mathrm{~g} \mathrm{~L}^{-1}$ was detrimental to shoot development in the blackberry explants (Figure 4A, 4B, 4C and 4D). In the in vitro culture, excess sucrose can inhibit chlorophyll synthesis and reduce the photosynthetic crop capacity (Yamada Sato,
1978), favouring the development of fungi and bacteria (Sousa et al., 2007).

Thus, according to the maximum point of the polynomial function estimation, $20.34 \mathrm{~g} \mathrm{~L}^{-1}$ sucrose is the most appropriate concentration (Figure 4). The highest numbers of shoots per explant (3.9) and leaves (26) occurred in the treatment with $10 \mathrm{~g} \mathrm{~L}^{-1}$ sucrose; however, the largest total length $(21 \mathrm{~mm})$, length of the largest shoot $(13 \mathrm{~mm})$ and fresh weight $(0.32 \mathrm{~g})$ were obtained with 30 $\mathrm{g} \mathrm{L}^{-1}$ sucrose.
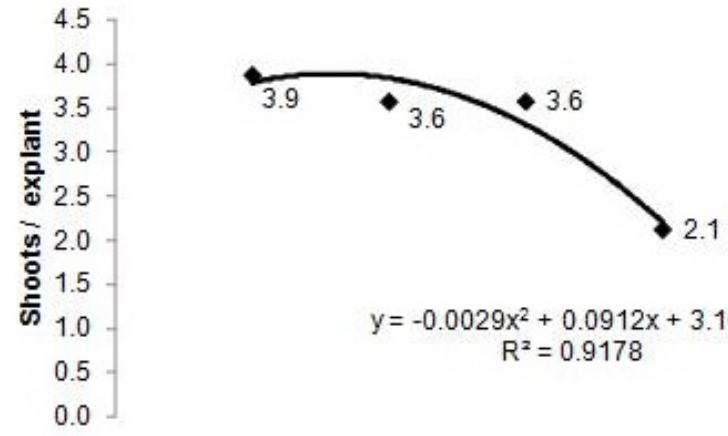

$y=-0.0029 x^{2}+0.0912 x+3.1625$

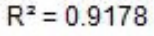

A
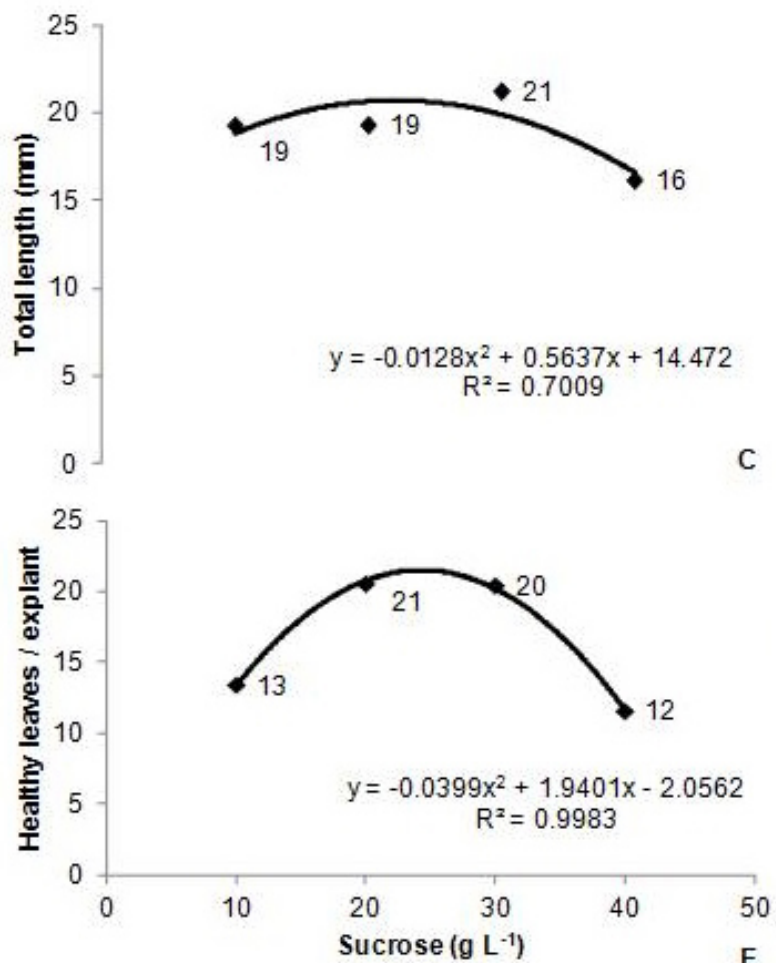
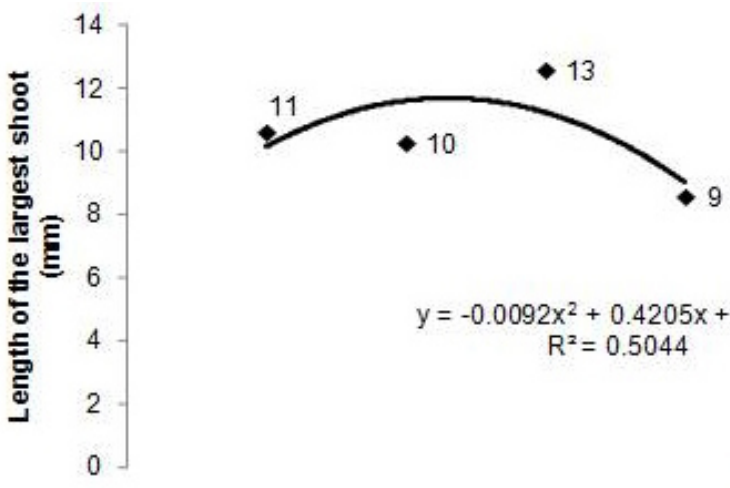

$y=-0.0092 x^{2}+0.4205 x+6.876$ $R^{2}=0.5044$
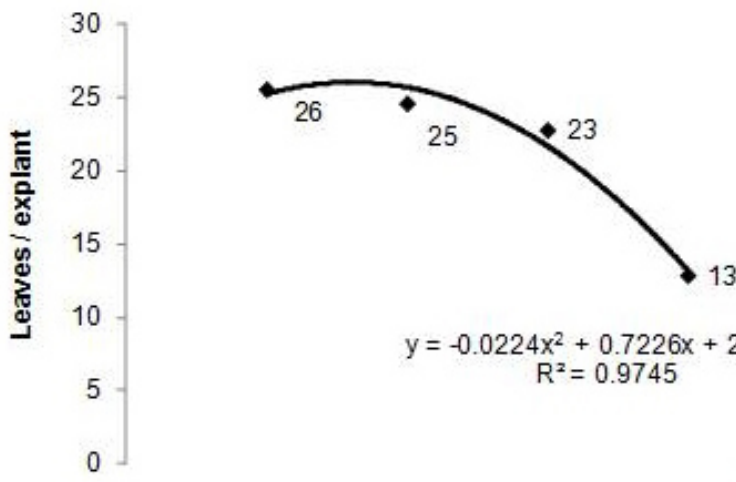
$\begin{aligned} y=-0.0224 x^{2} & +0.7226 x+20.256 \\ R^{2} & =0.9745\end{aligned}$

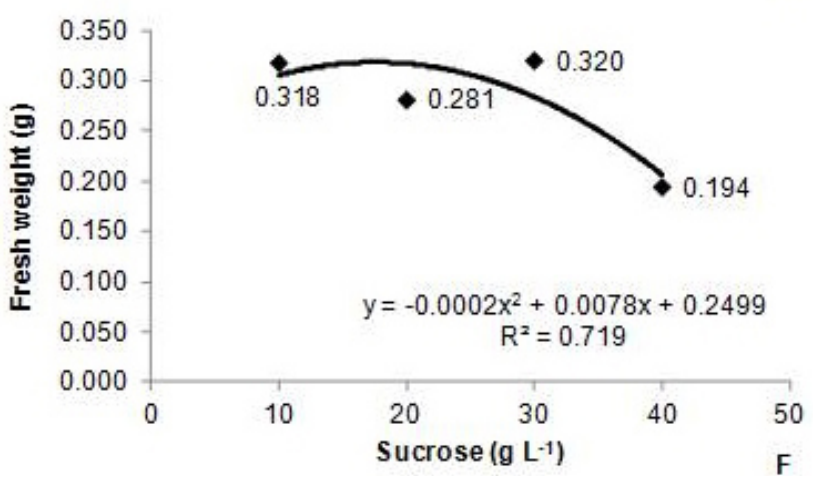

Figure 4: Sucrose influence on blackberry microshoot development in a temporary immersion bioreactor. A number of shoots per explant, B - length of largest shoot, C - total length, D - total number of leaves per explant, $\mathrm{E}$ - number of healthy leaves per explant, $\mathrm{F}$ - plant fresh weight. 
The influence of sucrose on the number of hyperhydric shoots can be seen in Figure 5 A, B and C. On the other hand, the liquid culture medium can induce hyperhydricity. This condition was frequently observed with $200 \mathrm{~mL}$ of medium (data not shown) and $10 \mathrm{~g} \mathrm{~L}^{-1}$ sucrose. In this sense, hyperhydricity may have occurred due to the high humidity, the liquid consistency of the medium (Vasconcelos et al., 2012), low transpiration (Dries et al., 2013) and high water potential. Ramírez-Mosqueda et al. (2016) also observed a high incidence of hyperhydricity, which was associated with the temporary immersion system. Debnath (2007) worked with Rubus chamaemorus clones and reported a 20 and $30 \%$ incidence of this disorder in two clones, which was attributed to the consistency of the culture medium. In the sucrose experiment, 34,71 g $\mathrm{L}^{-1}$ was estimated as the minimum point and refers to the ideal amount for this phenomenon not occurring; this value is very close to $30 \mathrm{~g} \mathrm{~L}^{-1}$, the concentration normally used.

Leaf mortality per explant is shown in Figure 6 D. In relation to dead leaves, the higher incidence in the hyperhydric shoots can be explained by the low gas exchange, which hinders ethylene exit, thus concentrating it in the cells and inducing foliar senescence. As noted by Ayub et al. (2017) in blueberry, silver thiosulfate, an ethylene receptor blocker, reduced senescence foliar symptoms, indicating that ethylene concentration in the container affects plant development. According to the minimum point of the polynomial function estimation, $34,71 \mathrm{~g} \mathrm{~L}^{-1}$ sucrose induced the worst hyperhydric conditions.

The lowest averages observed for hyperhydric shoot quantity, hyperhydric shoot length, number of hyperhydric leaves/explant and number of dead leaves/explant using $40 \mathrm{~g} \mathrm{~L}^{-1}$ sucrose (Figure 6) were in accord with Bandinelli et al. (2013), who verified that an increased sucrose concentration reduced the leaf number and the number of internodes in potato plants. Increasing the sucrose concentration also reduces the water potential gradient, which may have impaired the absorption of water and nutrients, thus explaining the lower medium and the absence of hyperhydric shoots. A sucrose concentration of 20 $\mathrm{g} \mathrm{L}^{-1}$ is indicated for the cultivation of blackberry, as confirmed by the concentration estimated through the derivative of the equations of the main variables (20.34 $\left.\mathrm{g} \mathrm{L}^{-1}\right)$. Values close to $15 \mathrm{~g} \mathrm{~L}^{-1}$ were obtained for raspberry (Arencibia et al., 2013) and pineapple (Silva et al., 2012).

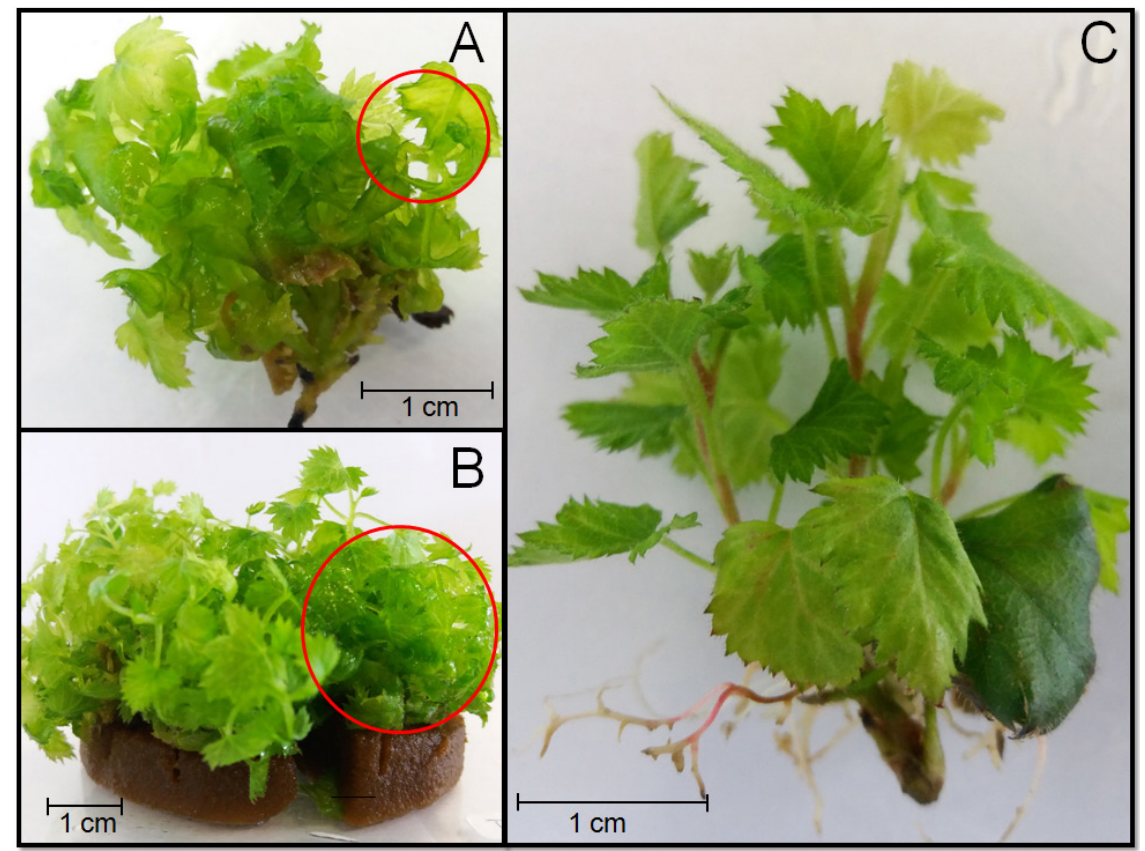

Figure 5: Hyperhydric shoots obtained with $10 \mathrm{~g} \mathrm{~L}^{-1}$ sucrose (A and B) compared with normal shoots obtained with $20 \mathrm{~g} \mathrm{~L}^{-1}$ sucrose (C) in a blackberry temporary immersion bioreactor. In the red circle, translucent leaves and hyperhydricity symptoms. 

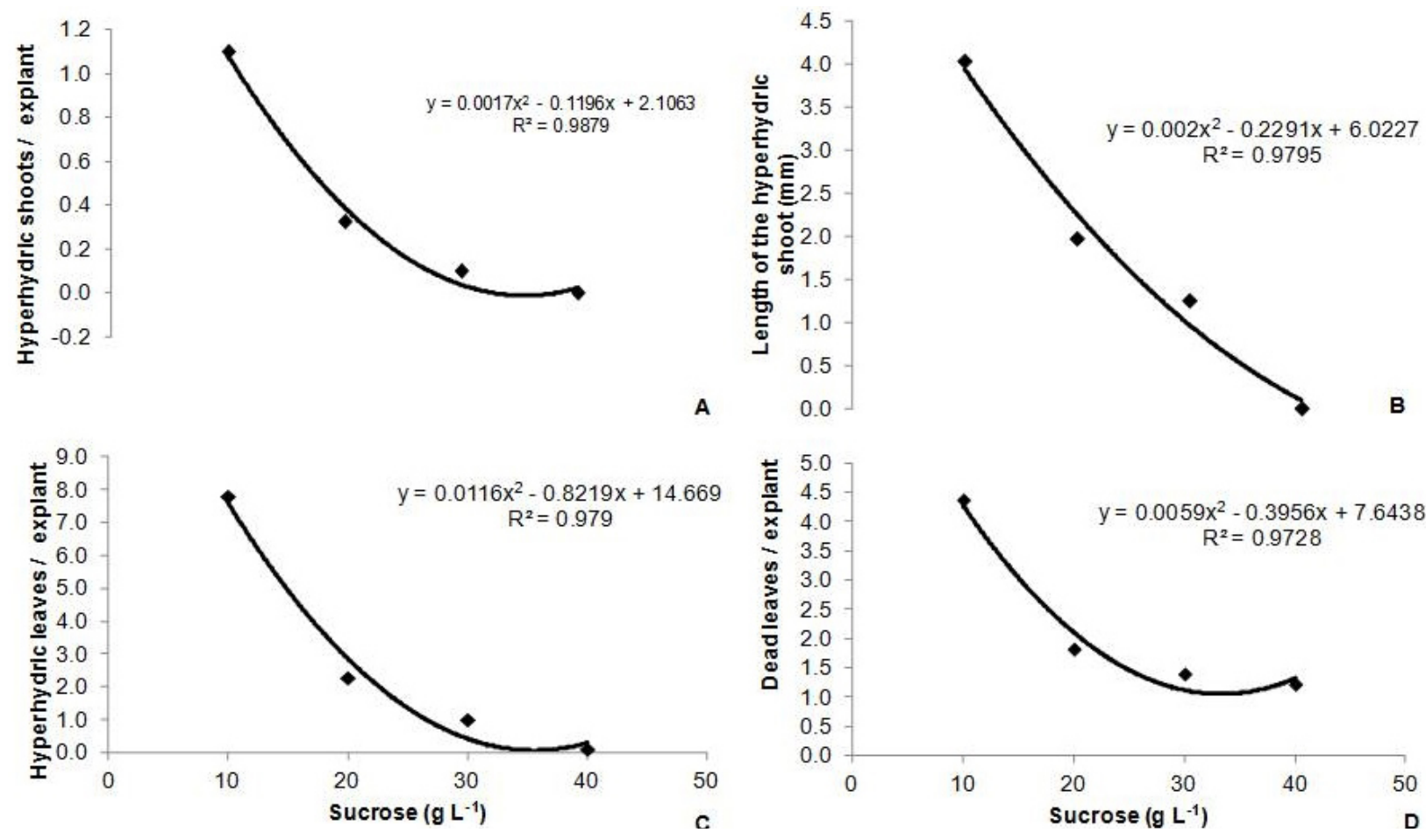

Figure 6: Sucrose influence on hyperhydric shoot quantity per explant (A), hyperhydric shoot length (B), number of hyperhydric leaves per explant (C) and number of dead leaves per explant (D) in a blackberry temporary immersion system.

\section{CONCLUSIONS}

A volume of liquid medium of $175 \mathrm{~mL}$ and a sucrose concentration of $20 \mathrm{~g} \mathrm{~L}^{-1}$ are recommended for blackberry cultivation in a temporary immersion bioreactor, while $10 \mathrm{~g} \mathrm{~L}^{-1}$ sucrose induces the phenomenon of hyperhydricity and is not indicated for cultivation. New studies should be performed to adjust the plant density and compare conventional micropropagation in solid medium with that in a bioreactor system.

\section{ACKNOWLEDGEMENTS}

This research was supported by Coordenação de Aperfeiçoamento de Pessoal de Nível Superior (CAPES), Conselho Nacional de Desenvolvimento Científico e Tecnológico (CNPq), and Universidade Estadual de Ponta Grossa (UEPG).

\section{REFERENCES}

ARENCIBIA, A. D. et al. Establishment of photomixotrophic cultures for raspeberry microproagation in Temporary
Immersion Bioreactors (TIBs). Scientia Horticulturae, 160(1):49-53, 2013.

ATTILIO, L. B.; BOLIANI, A. C.; TARSITANO, M. A. A. Prodution cost of blackberry crop in a tropical area. Revista Brasileira de Fruticultura, 31(4):1042-1047, 2009.

AUGUSTO, C. S. S.; BIASI, L. A.; TELLES, C. A. Rooting and acclimatization of micropropagated plants of blackberry cv. Brazos. Revista Brasileira de Fruticultura, 28(3):473476, 2006.

AYUB, R. A. et al. Blueberry (Vaccinium ashei Reade) cV. Brightwell in vitro establishment with silver thiosulfate. Plant Cell Culture \& Micropropagation, 13(1):1-6, 2017.

BANDINELLI, M. G. et al. MS salt and sucrose concentrations in the in vitro multiplication and acclimatization of potato. Horticultura Brasileira, 31(2):242-247, 2013.

DEBNATH, S. C. A two-step procedure for in vitro multiplication of cloudberry (Rubus chamaemorus L.) shoots using bioreactor. Plant Cell, Tissue and Organ Culture, 88(2): 185-191, 2007. 
DEBNATH, S. C. Bioreactor-induced adventitious shoot regeneration affects genotype- dependent morphology but maintains clonal fidelity in red raspberry. In vitro Cellular \& Developmental Biology - Plant, 50(6):777-788, 2014.

DEBNATH, S. C. Bioreactors and molecular analysis in berry crop micropropagation - A review. Canadian Journal of Plant Science, 91(1):147-157, 2011.

DRIES, N. V. et al. Flooding of the apoplast is a key factor in the development of hyperhydricity. Journal of Experimental Botany, 64(16):5221-5230, 2013.

ERIG, A. C.; ROSSI, A. de; FORTES, G. R. L. de. 6-benzylamino purine and indol butyric acid on the in vitro multiplication of blackberry (Rubus idaeus), cv. Tupy. Ciência Rural, 32(5):765-770, 2002.

FERREIRA, D. F. Sisvar: A guide for its bootstrap procedures in multiple comparisons. Ciência e Agrotecnolgia, 38(2):109112, 2014.

GEORGIEV, V. et al. Temporary immersion systems in plant biotechnology. Engineering in Life Sciences, 14(6):607621, 2014.

HAZARIKA, B. N. Morpho-physiological disorders in in vitro culture of plant. Scientia Horticulturae, 108(2):105-120, 2006.

HUNKOVÁ, J.; LIBIAKOVÁ, G.; GAJDOSOVÁ, A. Shoot proliferation ability of selected cultivars of Rubus spp. as influenced by genotype and cytokinin concentration. Journal of Central European Agriculture, 17(2):379-390 2016.

LEMES, C. S. R. et al. Meios de cultivo e sacarose no crescimento inicial in vitro de Miltonia flavescens. Ciência Rural, 46(3):499-505, 2016.

LEMOS, E. E. P. Micropropagação de plantas por biorreatores. In: JUNGHANS, T. G.; SOUZA, A. S. da. Aspectos práticos da micropropagação de plantas. Brasília: Embrapa. 95132,2013

MURASHIGE, T.; SKOOG, F. A revised medium for rapid growth and bioassays with tobaco tissue cultures. Physiologia Plantarum, 15(3):437-496, 1962.

RAMÍREZ-MOSQUEDA, M. A. et al. Micropropagation of Stevia rebaudiana Bert. in temporary immersion systems and evaluation of genetic fidelity. South African Journal of Botany, 106(1):238-243, 2016.
RIBEIRO, M. N. O. et al. Diferentes concentrações de sais do meio MS e de sacarose na multiplicação in vitro de Zantedeschia aethiopica L. Spreng. (copo-deleite). Revista Ciência Agronomica, 39(1):101-106, 2008.

RODRIGUES, P. H. V. et al. Propagation of heliconia plantlets in temporarily immersion bioreactor. Bragantia, 65(1):2935, 2006.

ROJAS-MARTÍNEZ, L.; VISSER, R. G. F.; KLERK, G. J. de. The hyperhydricity syndrome: Waterlongging of plant tissues as a major cause. Propagation of Ornamental Plants, 10(4):169-175, 2010.

SILVA, A. B. da. et al. Effect of Cyperus rotundus L. extract on rooting of blackberry. Revista CIENTEC, 8(1):1-9, 2016.

SILVA, A. B. da. et al. Natural light, sucrose and growth regulators on leaf anatomy and in vitro growth of micropropagated pineapple. Plant Cell Culture \& Micropropagation, 8(12):1-9, 2012.

SILVA, A. B. da. et al. Micropropagation methods of pineapple. Pesquisa Agropecuária Brasileira, 42(9):1257-1260, 2007.

SOUSA, G. C. et al. Contaminação microbiana na propagação in vitro de Cattleya walkeriana e Schomburgkia crispa. Revista Brasileira de Biociências, 5:405-407, 2007.

TEIXEIRA, J. B. Biorreator de Imersão Temporária - O futuro da produção industrial de plantas in vitro. In: GERALD, L. T. S. Biofábrica de plantas: produção industrial de plantas in vitro. São Paulo: Antiqua, p. 34-49, 2011.

TULLIO, L.; AYUB, R. A. Production of blackberry cv tupy, depending on the intensity of pruning. Semina: Ciências Agrárias, 34(3):1147-1152, 2013.

VASCONCELOS, A. G. V. de. et al. Hyperhydricity: A metabolic disorder. Ciência Rural, 42(5):837-844, 2012.

WELANDER, M. et al. Evaluation of new vessel system based on temporary immersion system for micropropagation. Scientia Horticulturae, 179(1):227-232, 2014.

YAMADA, Y.; SATO, F. The photoautotrophic culture of chlorophyllous cells. Plant Cell Physiology, 19(4):691699, 1978.

ZANLORENSI JUNIOR, L. A. et al. Temporary immersion bioreactor monitored by software. Brasil, BR202017008054 - 0, 19 Apr. 2017. 